
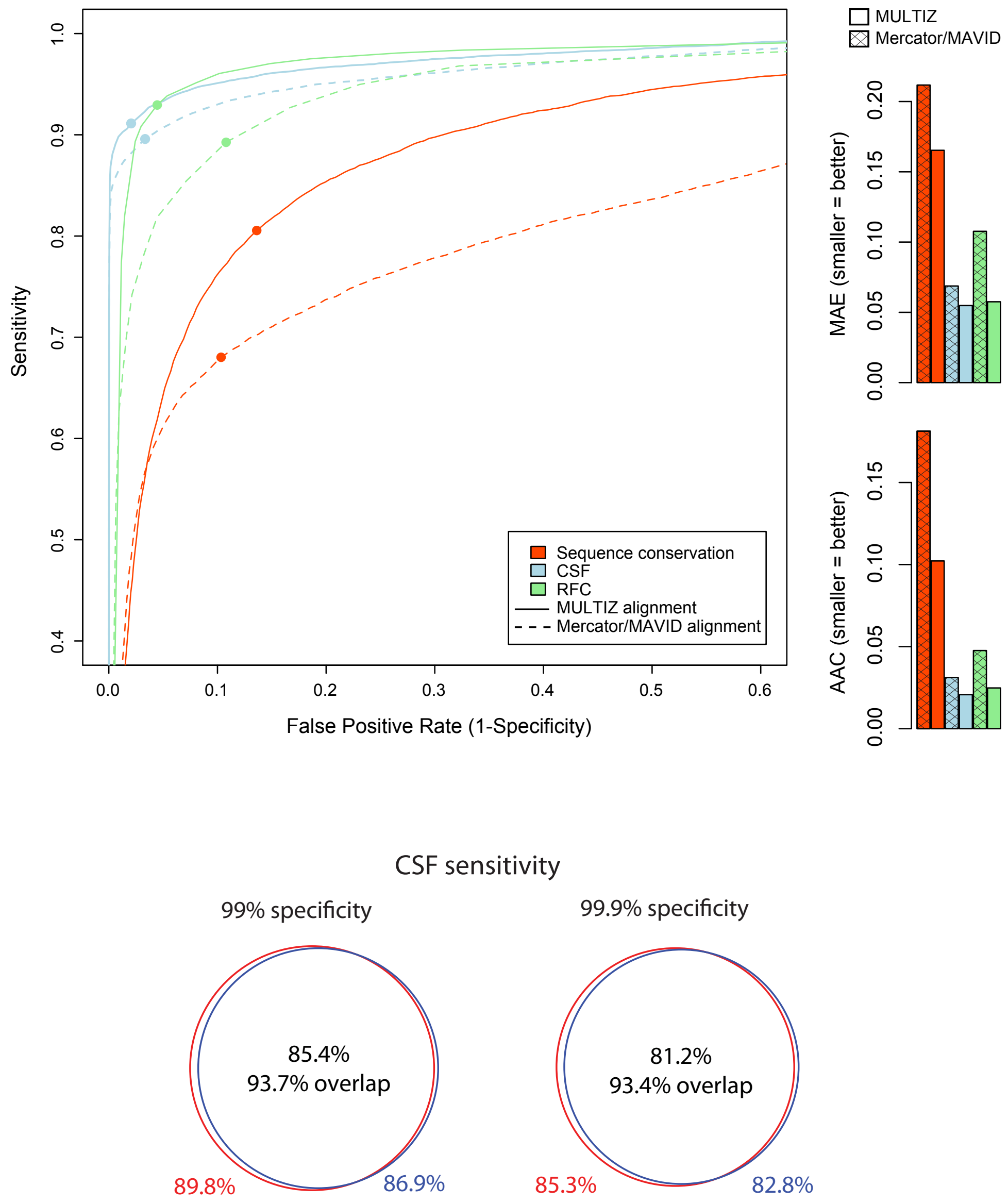

\title{
99.9\% specificity
}

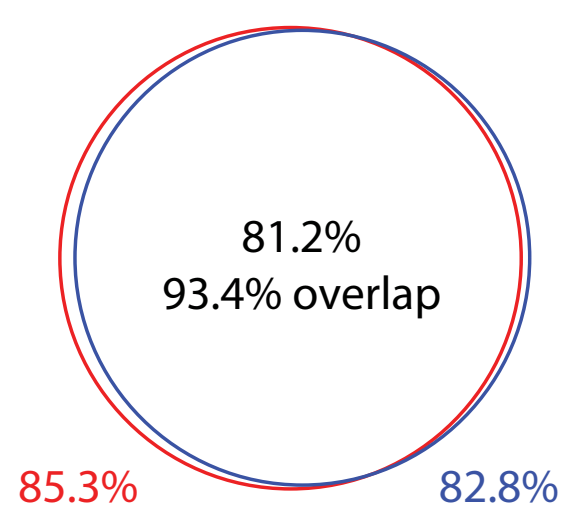

MULTIZ Mercator/MAVID 